\title{
Sağlık Bilimleri Fakültesi Öğrencilerinin Simülasyon Eğitimine İlişkin Bilgi Düzeyleri ve Farkındalıkları
}

\section{Faculty of Health Sciences Students' Knowledge Levels and Awareness on Simulation Education}

\author{
${ }^{1}$ Filiz ASLANTEKIN ÖZÇOBAN, ${ }^{2}$ Sibel ERGÜN, ${ }^{1}$ Pelin PALAS KARACA, ${ }^{3}$ Ayşe KARADAŞ, \\ ${ }^{2}$ Serap KAYNAK, ${ }^{4}$ Türkan ÇALIŞKAN
}

${ }^{1}$ Balıkesir Üniversitesi Sağlık Bilimleri Fakültesi, Ebelik Bölümü, Balıkesir, Türkiye

${ }^{2}$ Balıkesir Üniversitesi Sağlık Bilimleri Fakültesi, Hemşirelik Bölümü, Çocuk Sağlığı ve Hastalıkları Hemşireliği ABD, Balıkesir, Türkiye ${ }^{3}$ Balıkesir Üniversitesi Sağlık Bilimleri Fakültesi, Hemşirelik Bölümü, Hemşirelik Yönetim ABD, Balıkesir, Türkiye ${ }^{4}$ Balıkesir Üniversitesi Sağlık Bilimleri Fakültesi, Hemşirelik Bölümü, İç Hastalıkları Hemşireliği ABD, Balıkesir, Türkiye

Filiz Aslantekin Özçoban: https://orcid.org/0000-0002-0402-6959 Sibel Ergün: https://orcid.org/0000-0003-1227-5856

Pelin Palas Karaca: https://orcid.org/0000 000293366209

Ayşe Karadaş: https://orcid.org/0000-0003-3955-2980

Serap Kaynak: https://orcid.org/0000-0001-9482-5254

Türkan Çalışkan: https://orcid.org/0000-0002-7808-2363

\begin{abstract}
ÖZ
Amaç: Bu çalışmada Sağlık bilimleri fakültesi öğrencilerinin simülasyon eğitimine ilişkin bilgi düzeyleri ve farkındalıklarının belirlenmesi amaçlanmıştır.

Materyal ve Metot: Kesitsel tipte tasarlanan araştırma Aralık- Ocak 2019 tarihleri arasında bir devlet üniversitesinde öğrenim gören 568 ebelik ve hemșirelik öğrencileriyle yürütülmüştür. Çalışmanın verileri tanıtıcı bilgi formu ve simülasyon eğitimine ilişkin görüş formu ile toplanmıştır. Veriler frekans dağılımı ve ki-kare testi kullanılarak analiz edilmiştir.

Bulgular: Öğrencilerin \%25,7'si klinik uygulamaya çıkmadan önce aldığı eğitim sayesinde kendisini yeterl hissettiğini, dörtte üçü $(\% 73,6)$ ise klinik uygulama becerilerinin sanal ortamda senaryo/bilgisayar ve maket (simülasyon) kullanarak yapılmasını tercih ettiğini belirtmektedir. Okuduğu bölüm, sınıf, mezun olunan lise, bölümü isteyerek seçme ile klinik uygulamaya çıkmadan önce aldığı eğitim ve kendini yeterli algılama arasında anlamlı fark tespit edilmiştir $(p<0,05)$.

Sonuç: Araştırma sonucunda öğrencilerin büyük çoğunluğunun mesleki eğitimlerinde simülasyon eğitim almak istedikleri ve simülasyon eğitimine ilişkin olumlu bakış açıları olduğu tespit edilmiştir. Bu bulgular ışığında öğrenci eğitiminde simülasyon eğitimi kullanımı ile öğrencilerin mezuniyet öncesi yeterlik algıları olumlu yönde etkilenebilecektir

Anahtar Kelimeler: Ebelik, hemşirelik, inovasyon, simülasyon
\end{abstract}

\section{ABSTRACT}

Objective: In this study, it was aimed to determine the knowledge levels and awareness of the students of the Faculty of Health Sciences about simulation education.

Materials and Methods: The research, designed in a cross-sectional type, was conducted between December 2018 and January 2019 with 568 midwifery and nursing students studying at a public university. The data of the study were collected with an introductive information form and an opinion form on simulation training. The data were analyzed frequency distribution and chi-square test were used.

Results: $25.7 \%$ of students state they feel competent thanks to the training they received before going to clinical practice, while three quarters $(73.6 \%)$ state they prefer clinical practice skills to be done virtually using scenarios/ computers and models (simulations). Significant differences were found between the education received before starting clinical practice and self-perception in terms of the department, the class, the graduated high school, and willingly choosing the department.

Conclusion: As a result of the research, it was determined that the vast majority of students wanted to receive simulation training in their vocational training and had positive perspectives on simulation training. In light of these findings, students' perceptions of pre-graduation proficiency may be positively affected by the use of simulation training.

Keywords: Innovation, midwifery, nursing, simulation

\author{
Sorumlu Yazar / Corresponding Author: \\ Filiz Aslantekin Özçoban \\ Balıkesir Üniversitesi Sağlık Bilimleri Fakültesi Çağış Kampus, \\ Altıeylül Balıkesir \\ Tel: +905447696936 \\ E-mail: aslantekinfiliz@yahoo.com
}

Yayın Bilgisi / Article Info:

Gönderi Tarihi/ Received: 24/02/202

Kabul Tarihi/ Accepted: 30/09/2021

Online Yayın Tarihi/ Published: 01/12/2021

Atıf / Cited: Aslantekin Özçoban F ve ark. Sağlık Bilimleri Fakültesi Öğrencilerinin Simülasyon Eğitimine İlișkin Bilgi Düzeyleri ve Farkındalıkları. Online Türk Sağlık Bilimleri Dergisi 2021;6(4):583-590. doi:10.26453/otjhs.886301 


\section{GíRiş}

Ebelik ve hemşirelik eğitimi, teorik ve klinik uygulamalı öğrenmeleri içeren karmaşık bir süreçtir. Bu süreçte teorik bilginin klinik uygulama ile birleştirilmesi, eleştirel düşünme ve etkin problem çözme becerisinin kazandırılması hedeflenmektedir. Teorik ve klinik eğitimlerde bilişsel, duyuşsal ve psikomotor öğrenme alanlarına dayalı, aktif katılımın sağlandığı interaktif yöntemlerin kullanılması son derece önemlidir. Bu bağlamda gerçek yaşam olaylarını taklit ederek ya da klinik durumları açıklayarak, mantıklı düşünme, sorun çözme, karar verme becerilerini arttıran, tekrarlı deneme şansı sağlayan ve tıbbi hata riskini ortadan kaldıran simülasyon tekniği en etkili yöntemlerdendir. ${ }^{1-3}$

Dünya Sağlık Örgütü, ebelik ve hemşirelik eğitimöğretim süreçlerinde, teknolojideki gelişmelere paralel olarak güvenli, entegre, yüksek kaliteli, kanıta dayalı bakım ve eğitim yaklaşımlarının ve yöntemlerinin kullanılarak ebe ve hemşirelerin potansiyel kapasitelerinin en üst düzeye çıkarılmasını önermektedir. ${ }^{4} \mathrm{Bu}$ bağlamda özellikle son yıllarda mesleki beceri laboratuvarlarında standart hastaların, düşükyüksek gerçeklikli simülatörlerin, interaktif hasta simülatörlerinin ve bilgisayar temelli simülasyon uygulamalarının kullanımı yaygınlaşmaya başlamıştır. ${ }^{5,3}$ Yüksek gerçeklikli simülatörler aktif, öğrenci odaklı bir eğitim yöntemi olması bağlamında öğrencilerde gözlemsel tepkilere izin vererek bilgi, psikomotor beceri, iletişim ve klinik yeterliliklerini, eleştirel düşünmeyi, karar verme yeteneklerini geliştirmekte ve bilginin kalıcılığını arttırmaktadır. ${ }^{6,7}$ Simulasyon laboratuarında klinik ortam gerçekleştirilen uygulama eğitimleri ile gerçeğe yakın şekilde canlandırılabilir, özellikli hasta durumu sunulabilir, hatalar gösterilip, düzeltilebilir, tüm öğrencilere aktif öğrenme imkanı sağlanabilir. ${ }^{8,9}$ Ayrıca nadir görülen klinik durumların deneyimlenmesine firsat tanıan bir öğrenme yolu ile beceride yetkinliği artırırken, hastaya zarar verme korkusu yaşatmadan öğrenme imkanı da sunulur. ${ }^{10,11}$ Ayrıca, simülasyon beceri eğitimlerinin sınıf içi etkileşimleri arttırdığı, hem eğiticilerin hem de öğrencilerin klinik performansını olumlu yönde etkilediği, maliyeti ve personel ihtiyacını azalttığı bilinmektedir. ${ }^{12}$ Simülasyon eğitiminin, bireysel öğrenmeyi ve öğrencilerin memnuniyet oranını arttırdığı vurgulanmaktadır. ${ }^{13,14}$ Tüm bu nedenler, ebelik ve hemşirelik eğitiminde simülasyon uygulamalarının yaygınlaşmasını gerekli kılmaktadır. ${ }^{15}$ Tüm bu bilgiler 1şı̆̆ında bu çalışmanın amacı, bir devlet üniversitesinin sağlık bilimleri fakültesinde bilgisayar destekli simülasyon laboratuvarı kurulma aşamasında ebelik ve hemşirelik öğrencilerinin simülasyon eğitimine ilişkin görüşlerinin belirlenmesidir. $\mathrm{Bu}$ amaç doğrultusunda aşağıdaki sorulara yanıt aranmıştır;
- Sağlık bilimleri fakültesi öğrencilerinin simülasyon eğitimine ilişkin görüşleri nasıldır?

- Öğrencilerin tanıtıcı özelliklerine göre simülasyon eğitimi ile kendini yeterli hissetme durumları arasında fark var midir?

- Öğrencilerin tanıtıcı özelliklerine göre klinik uygulamalarda simülasyon eğitimi tercihleri arasinda fark var midir?

\section{MATERYAL VE METOT}

Araştırmanın yürütülebilmesi için Balıkesir Üniversitesi Girişimsel Olmayan Klinik Araştırmalar Etik Kurulu tarafından onay alınmıştır (Tarih:18.12.2019, karar No: 2019/200).

Tanımlayıcı ve kesitsel tipte olan araştırmanın evrenini 2019-2020 eğitim-öğretim yılında bir devlet üniversitesinde öğrenim gören ebelik ve hemşirelik öğrencileri oluşturmuştur ( $\mathrm{N}=1012)$. Araştırma örneklemini ise araştırma katılmayı kabul eden 568 hemşirelik ve ebelik öğrencisi oluşturmuştur. Araştırmada evrene ulaşma oranı \%56 olarak hesaplanmıştır. Araştırmaya katılım için öğrencilerin yazılı ve sözlü katılım onayı ile gönüllülüğü esas alınmıştır. Araştırmanın verileri Aralık-Ocak 2019 tarihleri arasında iki bölümden oluşan veri toplama aracı ile toplanmıştır. Veri toplama aracının ilk bölümünde tanıtıcı bilgi formu, ikinci bölümünde ise Simülasyon eğitimine ilişkin görüş formu yer almaktadır. Tanıtıcı bilgi formunda; öğrencilerin yaşı, cinsiyeti, bölümü, mezun oldukları okul, okuduğu bölümü isteyerek seçme durumu, ailede sağlık personeli olma durumunu içeren 9 soru yer almaktadır. Simülasyona eğitimine ilişkin görüş formunda; araştırmac1lar tarafından literatür doğrultusunda $a^{10,11,14,16}$ hazırlanan form, simülasyon eğitiminin, ebelik ve hemşirelik eğitiminde kullanılmasının ve öğrencilerin klinik uygulamaya çıkmadan önce simülatör üzerinde hasta bakımı uygulamasını deneyimlemenin faydalarına ilişkin öğrenci görüşlerini belirlemeye yönelik 26 ifade yer almaktadır. Öğrencilerin formda yer alan ifadelere katılma durumlarını "Evet, Hayır, Kararsızım" şeklinde belirtmeleri istenmiştir ve araştırma bulguları bu şekilde gösterilmiştir.

Veriler, SPSS 21 paket programı kullanılarak analiz edilmiştir. Öğrencilerin tanıtıcı özellikleri ve simülasyon eğitimine ilişkin görüşleri sayı ve yüzde ile değerlendirilmiştir. Öğrencilerin tanıtıcı özelliklerine göre simülasyon eğitimi ile kendini yeterli hissetme durumlarının ve kinik uygulamalarda simülasyon eğitimi tercihlerinin karşılaştırılmasında ise ki-kare testi kullanılmıştır. Anlamlılık değeri $\mathrm{p}<0,05$ olarak kabul edilmiştir.

\section{BULGULAR}

Çalışmaya katılan öğrencilerin \%59,5'i hemşirelik 
bölümünde, \%40,5'i ebelikte öğrenim görmektedir. Öğrencilerin \%72'si bölümünü isteyerek seçtiğini, $\% 36,4$ ü iş imkanından dolayı tercih ettiğini, \% 32,6 'sı da istediği meslek olduğu için tercih ettiğini, $\% 75,2$ 'si ailesinde sağlık personeli olmadığını belirtmiştir (Tablo1).

Tablo 2'de simülasyon eğitimine ilişkin yer alan önermelere öğrencilerin yanıtları verilmiştir. Önermelere genel olarak bakıldığında öğrenciler tarafından çoğunlukla evet yanıtı verildiği görülmektedir
(Tablo 2). Öğrencilerin \% 73,4’ü simülasyon eğitiminin "Klinik beceri eğitiminin, senaryo/bilgisayar ve maket (simulasyon) kullanarak simüle ortamda yapılması daha tercih edilir bir yöntem olduğunu ve \% 81,3'ü zorlandığı karmaşık uygulamaları deneme firsatı bulduğunu bildirmektedir. Öğrencilerin \% 82,6's1 simülasyon eğitimi ile gerçekçi bir ortamda destekleyici ve güvenli öğrenme imkânı sağlandığın1, \% 75,5'i de iletişim becerilerinin ve özellikle zor iletişim becerileri deneyimlerine imkân verdiğini

Tablo 1. Öğr enciler inin tanıtıcı özellikleri.

\begin{tabular}{|c|c|c|}
\hline Bölüm & $\mathbf{n}$ & $\%$ \\
\hline Hemşirelik & 338 & 59,5 \\
\hline Ebelik & 230 & 40,5 \\
\hline \multicolumn{3}{|l|}{ Cinsiyet } \\
\hline Kadın & 481 & 84,7 \\
\hline Erkek & 87 & 15,3 \\
\hline \multicolumn{3}{|l|}{ Sinıf } \\
\hline 1 & 157 & 27,6 \\
\hline 2 & 139 & 24,5 \\
\hline 3 & 225 & 39,6 \\
\hline 4 & 47 & 8,3 \\
\hline \multicolumn{3}{|l|}{ Mezun olunan lise } \\
\hline Anadolu Lisesi & 420 & 73,8 \\
\hline Sağlık Meslek Lisesi & 148 & 25,9 \\
\hline \multicolumn{3}{|c|}{ Bölümü isteyerek seçme } \\
\hline Evet & 411 & 72,4 \\
\hline Hayır & 157 & 27,6 \\
\hline \multicolumn{3}{|l|}{ Bölümü seçme nedeni } \\
\hline Yardım sevmek & 36 & 6,3 \\
\hline İș İmkanı & 207 & 36,4 \\
\hline İstediğim Meslek & 185 & 32,6 \\
\hline Aile İsteği & 102 & 18,0 \\
\hline Diğer & 38 & 6,7 \\
\hline \multicolumn{3}{|c|}{ Ailede sağlık personeli olma } \\
\hline Evet & 141 & 24,8 \\
\hline Hayır & 427 & 75,2 \\
\hline
\end{tabular}

Tablo 2. Öğr enciler in simülasyon eğitimine ilişkin görüşleri.

\begin{tabular}{|l|l|l|l|l|l|l|}
\hline & \multicolumn{2}{|l|}{$\begin{array}{l}\text { Evet } \\
\text { (n) }\end{array}$} & \multicolumn{2}{l|}{$\begin{array}{l}\text { Hayır } \\
\text { (n) \% }\end{array}$} \\
\hline $\begin{array}{l}\text { Klinik staja çımadan önce verilen eğitim öğrencinin ken- } \\
\text { dini yeterli hissetmesini sağlar. }\end{array}$ & $(146)$ & 25,7 & $(221)$ & 38,9 & \multicolumn{2}{l|}{$\begin{array}{l}\text { Kararsızım } \\
\text { \% }\end{array}$} \\
\hline $\begin{array}{l}\text { Klinik beceri eğitiminin, senaryo/bilgisayar ve maket } \\
\text { (simulasyon) kullanarak simüle ortamda yapıllması daha } \\
\text { tercih edilir bir yöntemdir. }\end{array}$ & $(417)$ & 73,4 & $(66)$ & 11,6 & $(85)$ & 15 \\
\hline Mevcut klinik eğitim deneyimine göre daha avantajlıdır & $(440)$ & 77,5 & $(20)$ & 3,5 & $(108)$ & 19,0 \\
\hline Öğrencinin kendi kendine öğrenmesini destekler. & $(442)$ & 77,8 & $(22)$ & 3,9 & $(104)$ & 18,3 \\
\hline $\begin{array}{l}\text { Öğrencinin anamnez almadan, işlem basamaklarına kadar, } \\
\text { tüm uygulamaları tam olarak gerçekleştirmesini sağlar. }\end{array}$ & $(402)$ & 70,8 & $(29)$ & 5,1 & $(137)$ & 24,1 \\
\hline $\begin{array}{l}\text { Öğrencinin zorlandığı karmaşık uygulamaları deneme } \\
\text { firsatı sağlar. }\end{array}$ & $(462)$ & 81,3 & $(19)$ & 3,3 & $(87)$ & 15,3 \\
\hline $\begin{array}{l}\text { Öğrenciye hastaya bakım verme açısından empati yeteneği } \\
\text { kazandırır. }\end{array}$ & $(421)$ & 74,1 & $(31)$ & 5,5 & $(116)$ & 20,4 \\
\hline $\begin{array}{l}\text { Hasta tarafindan sunulan şikâyetin kontrolünü sağlama } \\
\text { deneyimi kazandırır. }\end{array}$ & $(412)$ & 72,5 & $(30)$ & 5,3 & $(126)$ & 22,2 \\
\hline Öğrencilerin klinik becerilerimin gelişmesine katkı sağlar. & $(462)$ & 81,3 & $(14)$ & 2,5 & $(92)$ & 16,2 \\
\hline
\end{tabular}


Tablo 2. Öğrenciler in simülasyon eğitimine ilişkin görüşleri (Devam)

\begin{tabular}{|c|c|c|c|c|c|c|}
\hline & $\begin{array}{l}\text { Evet } \\
\text { (n) }\end{array}$ & & $\begin{array}{l}\text { Hayı } \\
\text { (n) }\end{array}$ & & $\begin{array}{l}\text { Kara } \\
\text { (n) }\end{array}$ & \\
\hline $\begin{array}{l}\text { Yapılan klinik hata ile ilgili hızlı geri bildirim verilmesini } \\
\text { sağlar. }\end{array}$ & $(429)$ & 75,5 & $(20)$ & 3,5 & $(119)$ & 21,0 \\
\hline $\begin{array}{l}\text { İletişim becerilerinin ve özellikle zor iletişim becerileri } \\
\text { deneyimlerini sağlar. }\end{array}$ & $(429)$ & 75,5 & $(20)$ & 3,5 & $(119)$ & 21,0 \\
\hline $\begin{array}{l}\text { Öğrencinin motivasyonunu arttır ve öğrenmeye cesaretlen- } \\
\text { dirir. }\end{array}$ & $(396)$ & 69,7 & $(30)$ & 5,3 & $(142)$ & 25,0 \\
\hline $\begin{array}{l}\text { Öğrencinin klinik uygulama deneyimi açısından özel bir } \\
\text { imkandır. }\end{array}$ & $(474)$ & 83,7 & $(14)$ & 2,5 & $(80)$ & 14,1 \\
\hline Öğrencinin klinik stresi/ anksiyetesini azaltır. & $(421)$ & 74,5 & $(22)$ & 3,9 & $(124)$ & 21,8 \\
\hline Öğrencinin özgüvenini arttırır. & (454) & 79,9 & (13) & 2,3 & (101) & 17,8 \\
\hline Öğrencinin öğrenmede sorumluluk almasını sağlar. & $(472)$ & 83,1 & $(12)$ & 2,1 & $(84)$ & 14,8 \\
\hline $\begin{array}{l}\text { Gerçekçi bir ortamda destekleyici ve güvenli öğrenme } \\
\text { imkân1 sağlar. }\end{array}$ & (469) & 82,6 & (14) & 2,5 & (85) & 15,0 \\
\hline T1bbi hataların azalmasını sağlar. & $(438)$ & 77,1 & $(21)$ & 3,7 & $(109)$ & 19,2 \\
\hline Hastaların aldıkları bakımın kalitesi artırır. & $(426)$ & 75,0 & $(23)$ & 4,0 & $(119)$ & 21,0 \\
\hline $\begin{array}{l}\text { Hasta hakları ihlallerine neden olabilecek uygulamaların } \\
\text { azalmasını destekler. }\end{array}$ & $(412)$ & 72,5 & $(22)$ & 3,9 & $(134)$ & 23,6 \\
\hline $\begin{array}{l}\text { Hastaların, öğrencilerin uygulama yapmasından dolayı } \\
\text { yaşadığı endişe azalır. }\end{array}$ & (416) & 73,2 & $(32)$ & 5,6 & (120) & 21,1 \\
\hline Gerçek hasta ile etkileşim zorunluluğu/ ihtiyacı azalır. & $(351)$ & 61,8 & $(47)$ & 8,3 & $(170)$ & 29,9 \\
\hline $\begin{array}{l}\text { Gerçek hastalarda kaynaklanan olumsuz durumların orta- } \\
\text { dan kalkmasını sağlar. }\end{array}$ & (353) & 62,1 & $(56)$ & 9,9 & (159) & 28,0 \\
\hline $\begin{array}{l}\text { Yapılan hataların ve/veya yapılabilecek ve/ hataların fark } \\
\text { edilip düzeltilebileceği güvenli öğrenme ortamı sağlar. }\end{array}$ & $(445)$ & 78,3 & $(20)$ & 3,5 & $(103)$ & 18,1 \\
\hline $\begin{array}{l}\text { Eğitimin amaçlarına uygun hasta merkezli problemler } \\
\text { geliştirme olanağı sağlar }\end{array}$ & $(432)$ & 76,1 & $(23)$ & 4,0 & (113) & 19,9 \\
\hline $\begin{array}{l}\text { Hastanın sağlık durumunun ve klinik problemin karmaşık- } \\
\text { lığını kontrol etmeyi sağlar }\end{array}$ & $(436)$ & 76,8 & (23) & 4,0 & (109) & 19,2 \\
\hline
\end{tabular}

Tablo 3. Öğrencilerin tanıtıcı özelliklerine göre klinik uygulamaya çıkmadan önce alınan eğitim ile kendini. yeterli hissetme durumlarının karşılaştırılması

\begin{tabular}{|c|c|c|c|c|c|c|c|c|}
\hline \multirow[t]{3}{*}{ Değişkenler } & \multicolumn{6}{|c|}{ Simülasyon eğitimi ile kendini yeterli hissetme } & \multicolumn{2}{|c|}{ Test değeri } \\
\hline & \multicolumn{2}{|c|}{ Yeterli } & \multicolumn{2}{|c|}{ Yetersiz } & \multicolumn{2}{|c|}{ Karasızım } & \multirow[t]{2}{*}{$\mathbf{X}^{2}$} & \multirow[t]{2}{*}{$\mathbf{p}$} \\
\hline & Sayı & $\%$ & Sayı & $\%$ & Sayı & $\%$ & & \\
\hline \multicolumn{9}{|l|}{ Cinsiyet } \\
\hline Kadın & 120 & 24,9 & 183 & 38 & 178 & 37 & \multirow[t]{2}{*}{3,625} & \multirow[t]{2}{*}{0,163} \\
\hline Erkek & 26 & 22,4 & 38 & 43,7 & 23 & 26,4 & & \\
\hline \multicolumn{9}{|l|}{ Bölüm } \\
\hline Hemşirelik & 77 & 22,8 & 145 & 42,9 & 116 & 34,3 & \multirow[t]{2}{*}{6,461} & \multirow[t]{2}{*}{$\mathbf{0 , 0 4 0}$} \\
\hline Ebelik & 69 & 30 & 76 & 33 & 85 & 37 & & \\
\hline \multicolumn{9}{|l|}{ Sinıf } \\
\hline 1 & 58 & 36,9 & 29 & 18,5 & 70 & 44,6 & \multirow[t]{4}{*}{42,083} & \multirow[t]{4}{*}{0,001} \\
\hline 2 & 29 & 20,9 & 64 & 46 & 46 & 33,1 & & \\
\hline 3 & 52 & 23,1 & 101 & 44,9 & 72 & 32 & & \\
\hline 4 & 7 & 14,9 & 27 & 57,4 & 13 & 27,7 & & \\
\hline \multicolumn{9}{|c|}{ Bölümü isteyerek seçme } \\
\hline Evet & 116 & 28,2 & 165 & 40 & 131 & 31,8 & \multirow[t]{2}{*}{9,474} & \multirow[t]{2}{*}{$\mathbf{0 , 0 0 9}$} \\
\hline Hayır & 30 & 19,2 & 56 & 35,9 & 70 & 44,9 & & \\
\hline \multicolumn{9}{|l|}{ Mezun olduğu lise } \\
\hline Anadolu lisesi & 103 & 24,5 & 155 & 36,9 & 162 & 38,6 & \multirow[t]{2}{*}{7,155} & \multirow[t]{2}{*}{$\mathbf{0 , 0 2 8}$} \\
\hline Sağlık meslek lisesi & 43 & 29,1 & 66 & 44,6 & 39 & 26,4 & & \\
\hline
\end{tabular}

$\mathrm{X}^{2}$ : Ki kare testi; $\mathrm{p}$ : Anlamlılık değeri $(<0,05)$

belirtmektedir.

Öğrencilerin tanıtıcı özelliklerine göre klinik uygulamaya çıkmadan önce alınan eğitimle kendilerini yeterli hissetme durumları karşılaştırıldığında; ebelik öğrencilerinin kendini daha fazla yeterli hissettiği, sağlık meslek lisesi mezunu olan ve 4. Sınıf öğrencilerinin kendilerini daha yetersiz hissettiği, bölümü istemeyerek seçenlerin yeterlilik konusunda kendilerini daha çok kararsız hissettiği ve aralarındaki farkın istatistiksel olarak anlamlı olduğu saptanmıştır $(\mathrm{p}<0,05)$ (Tablo 3).
Öğrencilerin tanıtıcı özelliklerine göre klinik uygulama becerilerinin simülasyon kullanılarak yapılmasını tercih erme durumları karşılaştırıldığında; ebelik öğrencilerinin, kadın öğrencilerin ve 2. Sınıf öğrencilerin, klinik uygulamalarında simülasyon eğitimini daha fazla tercih ettikleri ve aralarındaki farkın istatistiksel olarak anlamlı olduğu saptanmıştır $(\mathrm{p}<0,05)$, (Tablo 4). 
Tablo 4: Öğrencilerin tanıtıcı özelliklerine göre klinik uygulamalarda simülasyon eğitimi tercihlerinin karşılaştırılması.

\begin{tabular}{|c|c|c|c|c|c|c|c|c|}
\hline \multirow{3}{*}{ Değişkenler } & \multicolumn{6}{|c|}{ Simülasyon eğitimi tercihleri } & \multicolumn{2}{|c|}{ Test değeri } \\
\hline & \multicolumn{2}{|c|}{ İstiyorum } & \multicolumn{2}{|c|}{ İstemiyorum } & \multicolumn{2}{|c|}{ Karasızım } & \multirow[b]{2}{*}{$\mathbf{X}^{2}$} & \multirow[t]{2}{*}{$\mathbf{p}$} \\
\hline & Sayı & $\%$ & Sayı & $\%$ & Sayı & $\%$ & & \\
\hline \multicolumn{9}{|l|}{ Cinsiyet } \\
\hline Kadın & 363 & 75,5 & 54 & 11,2 & 64 & 13,3 & \multirow[t]{2}{*}{6,591} & \multirow[t]{2}{*}{$\mathbf{0 , 0 3 7}$} \\
\hline Erkek & 55 & 63,2 & 12 & 13.8 & 20 & 12,9 & & \\
\hline \multicolumn{9}{|l|}{ Bölüm } \\
\hline Hemşirelik & 233 & 68,9 & 45 & 39,3 & 60 & 50 & \multirow[t]{2}{*}{9,475} & \multirow[t]{2}{*}{$\mathbf{0 , 0 0 9}$} \\
\hline Ebelik & 185 & 80,4 & 21 & 9,1 & 24 & 10,4 & & \\
\hline \multicolumn{9}{|l|}{ Sinıf } \\
\hline 1 & 109 & 69,4 & 12 & 7,6 & 36 & 22,9 & \multirow[t]{4}{*}{15,602} & \multirow[t]{4}{*}{$\mathbf{0 , 0 1 6}$} \\
\hline 2 & 110 & 79,1 & 16 & 11,5 & 13 & 9,4 & & \\
\hline 3 & 161 & 71,6 & 33 & 14,7 & 31 & 13,8 & & \\
\hline 4 & 37 & 78,7 & 5 & 10,6 & 5 & 10,6 & & \\
\hline \multicolumn{9}{|c|}{ Bölümü isteyerek seçme } \\
\hline Evet & 304 & 73,8 & 51 & 12,4 & 57 & 13,8 & \multirow[t]{2}{*}{2,051} & \multirow[t]{2}{*}{0,359} \\
\hline Hayır & 113 & 72,4 & 15 & 9,6 & 28 & 17,9 & & \\
\hline \multicolumn{9}{|l|}{ Mezun olduğu lise } \\
\hline Anadolu lisesi & 303 & 72,1 & 51 & 12,1 & 66 & 15,7 & \multirow[t]{2}{*}{1,340} & \multirow[t]{2}{*}{0,512} \\
\hline Sağlık meslek lisesi & 114 & 77 & 15 & 10,1 & 19 & 12,8 & & \\
\hline
\end{tabular}

\section{TARTIŞMA VE SONUÇ}

Ebelik ve hemşirelik eğitiminde bilgi ve becerinin kazandırılması ve geliştirilmesi için pek çok eğitim yöntemi ve stratejisi kullanılmaktadır. Günümüzde bu eğitim yöntem ve stratejilerinin en önemli grubunu simülasyon eğitimleri oluşturmaktadır $(3,7,14)$. Özellikle son yıllarda öğrenci kontenjanlarının artırılması ve klinik uygulama alanlarındaki sınırlamalar nedeniyle öğrencilerin klinik deneyim kazanabilmelerinde güçlükler yaşanmaktadır. Bu güçlükler ve simülasyon eğitiminin yararları göz önüne alınarak ülkemizde de simülasyon eğitimi uygulamaları yaygınlaşmaya başlamıştır (14). Çalışmada öğrencilerin çoğunluğunun simülasyon eğitimine olumlu bakış açıları olduğu aynı zamanda hayır ve kararsızım cevabı veren öğrenci oranlarına bakıldığında ise simülasyon yöntemine ilişkin bilgi eksiklikleri olduğu görülmektedir.

Araştırmada öğrencilerin çoğunluğu okuduğu bölümü isteyerek seçtiğini bildirmektedir. Mesleki gelişim ve eğitim süreçlerine etkisi bakımından olumlu olarak değerlendirilen bu durum, literatürde yapılan çalışma bulgularıyla benzerlik göstermektedir. ${ }^{17-19}$ Türkiye'de hemşirelik ve ebelik eğitim programları kuramsal dersler, laboratuvar uygulamaları ve klinik uygulamaları içermektedir. Öğrenciler, genellikle, hemşirelik ve ebelik eğitiminin ilk yılından itibaren klinik uygulama alanlarında hemşirelik ve ebelik uygulamalarını deneyimlerler. ${ }^{20}$

Araştırmada, klinik uygulamaya çıkmadan önce al1nan eğitimle ebelik öğrencileri kendilerini yeterli hissettiğini bildirirken, hemşirelik öğrencilerinin çoğunluğu yetersiz ya da yeterlilik konusunda kararsız hissetmektedir. Literatürde benzer şekilde hemşirelik öğrencilerinin çoğu kliniğe çıktıklarında, beceri uygulaması konusunda kendilerini yetersiz hissettik- lerini ve klinik öncesi eğitimin eksik kaldığını belirtmişlerdir. ${ }^{14,21}$ Simülasyon eğitim yönteminin öğrenci yeterliliklerinin değerlendirilmesine ve ayrıca öğrencilerin memnuniyet ve öz yeterliliklerinin gelişmesine katk1 sağlayan bir öğrenme yöntemi olduğu belirtilmektedir. ${ }^{16} \mathrm{Bu}$ doğrultuda, ebelik ve hemşirelik eğitimi için sağlık bilimleri fakültelerinde bilgisayar destekli simülasyon laboratuvarı kurulması, öğrencilerde tespit edilen yetersizliklerin azaltılmasını sağlayabilecektir.

Ebelik ve hemşirelik eğitim süreci içerisinde yer alan klinik uygulamalar öğrencilerin bilgi, beceri, uygulamalarını ve mesleği algılayışlarını güçlendirmektedir. ${ }^{22}$ Araştırmada, mezuniyet aşamasına gelen 4. Sınıf öğrencilerinin klinik uygulamaya çıkmadan önce alınan eğitimle kendilerini yetersiz hissetmesi özellikle üzerinde durulması gereken bir noktadır. Yapılmış bir çalışmada yeni mezun hemşirelerin psikomotor becerileri gerçekleştirme ve acil durumlara tepki verme konusunda hazır olma yeterliliğini "düşük" olarak değerlendirmişlerdir. ${ }^{23}$ Yeni mezunları dinamik bir işgücüne girmeye hazırlamak için simülasyon kullanımı, karmaşık hastalara bakmak için gereken beceri edinme, eleştirel düşünme ve eğitimi geliştirmek için etkili bir strateji olarak gösterilmektedir. ${ }^{24}$ Yeni mezunların yeni rollerine geçişlerini sağlamak hayati önem taşıdığından yetersizlik alanlarının ve kaynaklarının tespit edilmesi ve gerekli simülasyon eğitimlerinin mezuniyet öncesinde planlanması ve uygulanması öğrencilerin mesleğe giriş aşamasında stres, anksiyete ve çatışma yaşamalarını engelleyebilecektir.

Araştırmada, bölümü isteyerek seçmeyenlerin klinik uygulamaya çıkmadan önce alınan eğitimle kendilerini yeterli hissetme konusunda kendilerini daha çok kararsız hissettiği tespit edilmiştir. Okuduğu bölümü 
isteyerek seçen öğrencilerin eğitimleri sırasında klinik öncesinde, sırasında ve sonrasında daha az kaygı ve stres yaşarken, motivasyon, özgüven ve iyimserlik düzeylerinin daha yüksek olduğu bildirilmektedir. ${ }^{25,26}$ Okudukları bölümü isteyerek seçmeyen öğrenciler için klinik eğitim süreçlerinde yeterliklerini iyileştirmeye yönelik motivasyon kaynakları belirlenmelidir.

Araştırmada, sağlık meslek lisesi mezunlarının çoğunluğunun klinik eğitim öncesi alınan eğitimle kendilerini yetersiz hissettikleri tespit edilmiştir. Araştırma bulgusunun aksine, sağl1k meslek lisesi mezunu olan ögrencilerin lise eğitimleri sürecinde klinik alan deneyimleri nedeniyle kendilerini daha fazla yeterli hissetmesi beklenirdi. Yeterli hissetme durumu öğrencilerin bireysel algılarına göre şekillendiğinden sağlık meslek lisesi öğrencilerle yapılabilecek derinlemesine görüşmelerle yetersizlik nedenlerine yönelik ek araştırmalar ve girişimlere ihtiyaç olduğu görülmektedir.

Hasta güvenliği, etik ve yasal yaptırımlar, sağlık eğitiminde birçok becerinin kazandırılmasında gerçek hastalar üzerinde yapılmasını sınırlamıştır. Son yıllarda eğitimde çözüm olarak, birçok üstün yanı olduğu belirtilen simülasyonun kullanımı tercih edilmektedir. ${ }^{27}$ Araştırmada öğrencilerin çoğunluğu klinik uygulama becerilerinin sanal ortamda senaryo/bilgisayar ve maket (simülasyon) kullanarak yapılmasını tercih ettiğini belirtmektedir. Yapılan bir çalışmada, öğrencilerin özellikle sanal gerçeklik simülasyonunun ruh sağlığ hemşireliği uygulamalarında oldukça gerekli olduğunu belirttikleri gösterilmiştir. $^{28}$ Araştırmada ebelik öğrencilerinin, klinik uygulamalarında simülasyon eğitimini daha fazla tercih ettikleri saptanmıştır. Ülkemizde öğrenci sayısının fazlalığı ve öğrenciler için klinik alan yetersizliği nedeniyle özellikle ebelik öğrencilerinin mezuniyet kriterlerini tamamlayabilmesi noktasında klinik alanlarda yetersizlikler yaşanmaktadır. Ebelik öğrencileri, mezuniyet kriterlerini tamamlama stresiyle birlikte beceride yetersizlik hissini daha sık yaşamaktadır. ${ }^{29} \mathrm{Bu}$ nedenle simülasyon eğitimini daha fazla tercih ettikleri düşünülmektedir. Simülasyon ve beceri eğitimi, ebelik becerilerinin gelişimini destekler. Ebelik öğrencileriyle yürütülen bir çalışmada benzer şekilde öğrencilerin çoğu, uygulamalı becerileri geliştirmek için simülasyon ve beceri eğitiminin gerekli olduğunu düşünmüşlerdir. ${ }^{30}$ Araştırmada, kız öğrencilerin ve 2. Sınıf öğrencilerinin klinik uygulamalarında simülasyon eğitimini daha fazla tercih ettikleri görülmüştür. Görülen farklılıkların öğrenci sayılarının dağılımından ve öğrencilerin bireysel algılamalarından kaynaklanabileceği düşünülmektedir. Gruplar arasındaki farklılıklara rağmen genel olarak oranlara bakıldığında öğrencilerin çoğunluğunun simülasyon eğitimini tercih etmesi ve istemesi eğitim amaçlarına ulaşma konusunda önemli bir başlangıç olması adına olumlu bir sonuç olarak değerlendirilmektedir.

Araştırma sonucuna göre öğrencilerin çoğunluğu klinik uygulamaya çıkmadan önce aldıkları eğitimle kendilerini yeterli hissetmemekte ve klinik uygulama becerilerinin sanal ortamda senaryo/bilgisayar ve maket (simülasyon) kullanarak yapılmasını tercih etmektedir. Öğrencilerin çoğunluğunun simülasyon eğitim yöntemlerine olumlu bakış açıları olmasına rağmen bilgi eksiklikleri olduğu görülmektedir. Algılanan yetersizliklerin ortadan kaldırılması için mevcut eğitim yöntemlerinin gözden geçirilmesi ve kanıta dayalı olarak yararları ortaya konulan simülasyon eğitim yöntemleri uygulanmaya başlamalıdır. Özellikle hemşirelik öğrencilerinin ve son sınıfta okuyan ebelik ve hemşirelik öğrencilerinin klinik uygulamalara ilişkin yetersizlik alanlarının ve nedenlerinin tespit edilerek gerekli girişimlerin planlanması önerilmektedir.

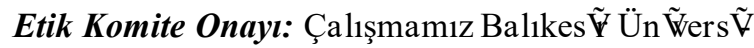
tesi Girişimsel Olmayan Klinik Araştırmalar Etik Kurulu tarafindan onaylandı (Tarih:18.12.2019, karar No: 2019/200).

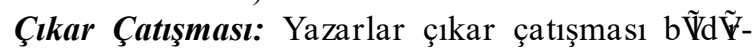
memişlerdir.

Yazar Katkıları: F $\tilde{\mathrm{K}} \tilde{\mathrm{V}}$ - FAÖ, SK, SE, AK; Denetleme - FAÖ, SE, SK, AK, TÇ; Malzemeler- FAÖ, AK, SK; Veri toplanması ve işlemesi - FAÖ, AK, PPK, SK; Analiz ve yorum - FAÖ, SE, AK, PPK Yazıyı yazan - FAÖ, AK, SE, PPK, SK, TÇ.

Hakem Değerlendirmesi: Dış bağımsız.

Teşekkür: Çalışmaya katılan öğrencẼer kür ederiz.

Finansal Destek: Bu araştırma Güney Marmara Kalkınma Ajansı desteği ile yürütülen proje kapsamında gerçekleştirilmiştir. "Sağlıkta Mesleki Yeterliliğin Eğitimsel Formülü: Simülasyon" GMKA PROJESİ (TR 22/18/MEG2MDP/0050).

Diğer: Bu araştırma, 12- 13 Ocak 2021 tarihinde 3. Uluslararası Sağlık Bilimleri ve İnovasyon Kongresinde sözel bildiri olarak sunulmuştur.

\section{KAYNAKLAR}

1. Chitongo S, Suthers F. Use of technology in simulation training in midwifery. British Journal of Midwifery. 2019;27(2):85-89. doi:10.12968/ bjom.2019.27.2.85.

2. McAllister M, Levett-Jones T, Downer T, ve ark. Snapshots of simulation: creative strategies used by Australian educators to enhance simulation learning experiences for nursing students. Nurse Education in Practice. 2013;13(6):567-572.

3. Sarı D, Erdem H. Hemşirelik eğitiminde yüksek gerçekli simülasyon kullanımı: literatür incelemesi. Journal of Human Sciences. 2017;14(4):36903707. doi:10.14687/jhs.v14i4.4882. 
4. World Health Organization. Simulation in nursing and midwifery education 2018. http:// www.euro.who.int/data/assets/ pdf_file/0011/383807/snme-report-eng.pdf?ua=1. Erişim tarihi 22 Şubat 2021.

5. Gündoğdu H, Dikmen Y. Hemşirelik eğitiminde simülasyon. Sanal gerçeklik ve haptik sistemler. J Hum Rhythm. 2017;3(4):172-176.

6. Akalın A, Şahin S. Simülasyona dayalı hemşirelik eğitiminde kuramlar. Sağlık Bilimleri ve Meslekleri Dergisi. 2019:6(1):136-143.

7. Sezer H, Orgun F. Hemşirelik eğitiminde simülasyon kullanımı ve simülasyon modeli. Ege Üniversitesi Hemşirelik Fakültesi Dergisi. 2017;33 (2):140-152.

8. Öztürk Dönmez R, Bayık Temel A. Klasik eğitim ve entegre eğitim modeli ile öğrenim gören hemşire öğrencilerin kişisel değerlerinin karşılaştırılması. Ege Üniversitesi Hemşirelik Fakültesi Dergisi. 2013;29(1):30-44

9. Dönmez S, Karaöz Weller B. Hemşirelik son sınıf öğrencilerinin aldıkları eğitime ilişkin görüşlerinin incelenmesi. ACU Sağlık Bil Derg. 2019;10 (1):42-48.

10. Akın Korhan E, Akbıyık A, Kırşan M, Namık E, Uzelli Y1lmaz D, Ceylan B, Tokem Y. Senaryotemelli simülasyon yönteminin öğrencilerin özetkinlik algı düzeyleri üzerindeki etkisi. İzmir Kâtip Çelebi Üniversitesi Sağlık Bilimleri Fakültesi Dergisi. 2019;4(1):13-17.

11. Li AML. Simulation-based clinical skill training to promote effective clinical learning with simulation evaluation rubrics in nursing education. International Journal of Information and Education Technology. 2016;6(3):237-242.

12. Motola I, Devine LA, Chung HS, Sullivan JE, Issenberg SB. Simulation in healthcare education: a best evidence practical guide. AMEE Guide No. 82. Med Teach. 2013;35(10):e1511-30. doi:10.3109/0142159X.2013.818632

13. Edward MI, Chukwuka L. Simulation in nursing education: implications for nurse educators and nursing practice. African Journal of Health, Nursing and Midwifery. 2020;3(1):13-23.

14. Terzioğlu F, Kapucu S, Özdemir L, ve ark. Simülasyon yöntemine ilişkin hemşirelik öğrencilerinin görüşleri. Sağlık Bilimleri Fakültesi Hemşirelik Dergisi. 2012;16-23.

15. MacLean S, Geddes F, Kelly M, Della P. Video reflection in discharge communication skills training with simulated patients: a qualitative study of nursing students' perceptions. Clin Simul Nurs. 2019;28(3):15-24

16. Uzelli Yılmaz D, Akın Korhan E. Hemşirelik eğitiminde simülasyon yönteminin etkinliği: bir sistematik inceleme. Türkiye Klinikleri Hemşirelik Dergisi. 2017;9(3):218-26. doi:10.5336/ nurses.2017;54737

17.Dinç A, Cangöl E, Söğüt S. Ebelik öğrencilerinin mesleki tercih hakkında düşünceleri. Cumhuriyet Üniv. Sağ. Bil. Enst. Derg. 2017;(2)2:15-23.

18. Seval M, Sönmez M. Hemşirelik öğrencilerinin mesleğe yönelik tutumları ve imaj algıları arasındaki ilişki. Sağlık Akademisi Kastamonu. 2020;5 (1):19-35.

19. Taşkıran N, Kalı N, Kıvrak EN, Türkseven N, Yıldırım GÖ. Son sınıf hemşirelik öğrencilerinin hemşirelik mesleğine, rollerine ve mesleğin geleceğine ilişkin görüşleri. Hastane Öncesi Dergisi. 2020;5(1):43-56.

20. Özsaban A, Bayram A. Türkiye'de hemşirelik öğrencilerinin klinik uygulama deneyimlerini etkileyen faktörler: sistematik derleme. Ankara Sağlık Bilimleri Dergisi. 2020;9(2):124-145.

21. Çetinkaya Uslusoy E. Hemşirelik eğitiminde simülasyon kullanımı: öğrencilerin görüşleri. SDÜ Sağlık Bilimleri Enstitüsü Dergisi. 2018;9(2):1318.

22. Jack K, Hamshire C, Harris WE, Langan M, Barrett $\mathrm{N}$, Wibberley C. My mentor didn't speak to me for the first four weeks: Perceived unfairness experienced by nursing students in clinical practice settings. J Clin Nurs. 2018; 27:929-938.

23. Schoening AM, Sittner BJ, Todd MJ. Simulated clinical experience: nursing students' perceptions and the educators' role. Nurse Educ. 2006;31 (6):253-8. doi:10.1097/00006223-20061100000008

24. McGaghie WC, Issenberg SB, Cohen ER, Barsuk JH, Wayne DB. Does simulation-based medical education with deliberate practice yield better results than traditional clinical education? A meta -analytic comparative review of the evidence. Acad Med. 2011;86(6):706-711.

25. Aslan H. Aktürk U. Nursing education stress levels of nursing students and the associated factors. Annals of Medical Research. 2018;25(4):660 $-6$.

26. Dağlar G, Bilgiç D, Evcili F, Bolat Ö. The relationship between self-efficacy-sufficiency and professional motivation of the midwifery students. International Journal of Caring Sciences. 2018;11 (2):1238-1246.

27. Durmaz Edeer A, Sarıkaya A. Hemşirelik eğitiminde simülasyon kullanımı ve simülasyon tipleri. Hemşirelikte Eğitim ve Araştırma Dergisi. 2015;12(2):121-125.

28. Han DL. Nursing students' perception of virtual reality(vr) and needs assessment for virtual reality simulation in mental health nursing. Journal of Digital Contents Society. 2020;21(8):1481-1487.

29. Yüksek Öğretim Kurumu. Mezuniyet öncesi ebelik ulusal çekirdek eğitim programı, 2016. https:// www.yok.gov.tr/Documents/Kurumsal/ 
egitim_ogretim_dairesi/Ulusal-cekirdek-egitimiprogramlari/ebelik.pdf. Erişim tarihi 22 Şubat 2021.

30. Lendahls L, Oscarsson MG. Midwifery students' experiences of simulation- and skills training. Nurse Education Today. 2017;50:12-16. 